\title{
Credit assessment practice of a commercial bank in Bangladesh
}

\author{
Rana-Al-Mosharrafa \\ Department of Business Administration, Prime University, Dhaka, Bangladesh
}

\section{Email address:}

mosharrafa74@yahoo.com

\section{To cite this article:}

Rana-Al-Mosharrafa. Credit Assessment Practice of a Commercial Bank in Bangladesh. International Journal of Economics, Finance and Management Sciences. Vol. 1, No. 6, 2013, pp. 382-387. doi: 10.11648/j.ijefm.20130106.25

\begin{abstract}
The banks act as an intermediary to mobilize the excess fund of surplus sectors to provide necessary finance, to those sectors, which are needed to promote for the sound development of the economy. Credit management is a dynamic field where a certain standard of long-range planning is needed to allocate the fund in diverse field and to minimize the risk and maximizing the return on the invested fund. Credit risk grading technique is an important tool for credit management as it helps a bank to understand various dimensions of risk involved in different credit transactions. The main purpose of this study is to make possible suggestions to improve present credit situation prevailing in the banking sector in Bangladesh by analyzing a reputed commercial bank's credit activity. The study was undertaken to get an in depth idea of the credit appraisal system of a commercial bank and understand its importance. Beside this a case study of a well known commercial bank's credit appraisal and risk grading technique were also revealed to identify some problems as well as propose some suggestions in this regard. From the study it was evident that the bank, maintained standard credit management policy in the changing market situation to establish a set of credit management policy.
\end{abstract}

Keywords: Credit Assessment, Commercial Bank, Credit Management, Credit Risk Grading

\section{Introduction}

In Bangladesh the strength of the banking system is very vital because the capital market is little developed here. As the banks are still the major sources of credit and exercise great influence on the financial system, it is extremely important that the country's banking systems should be in good health in the interest of investment activities meeting the needs of all kinds of finance and related matters. Credit management is a dynamic field where a certain standard of long-range planning is needed to allocate the fund in diverse field and to minimize the risk and maximizing the return on the invested fund. The word credit comes from the Latin word "Credo" meaning "I believe". It is a lender's trust in a person's/ firm's/ or company's ability or potential ability and intention to repay. In other words, credit is the ability to command goods or services of another in return for promise to pay such goods or services at some specified time in the future. For a bank, it is the main source of profit and on the other hand, the wrong use of credit would bring disaster not only for the bank but also for the economy as a whole. In addition, the ability to allocate credit efficiently of a banking sector is expected to have positive implications for economic growth [1]. The banks take the funds from the depositors and use them in lending activities [2]. According to Allen and Santomero (1996) [3], banks play the role of financial intermediaries.

The goal of the credit management is to maximize the performing asset and the minimization of the nonperforming asset as well as ensuring the optimal point of loan and advance and their efficient management. The overall success in credit management depends on the banks credit policy, portfolio of credit, monitoring, supervision and follow-up of the loan and advance. Continuous supervision, monitoring and follow-up are highly required for ensuring the timely repayment and minimizing the default. Actually the credit portfolio not only constitutes the bank's asset structure but also is a vital factor of the bank's success. Only a proper credit analysis will bring to light the probability of credit loss arising out of genuine business factors and explore the possible mitigates regarding this ominous situation to put a check on it.

According to Basel Committee on Banking Supervision (1999) [4], credit can be defined as 'a transaction between two parties which one (the creditor or lender) supplies money or monetary equivalent goods services, etc. in return for a promise of future payment by the other (the debtor or 
borrower)'. From the banker's point of view, credit is the confidence of the lender on the ability and willingness of the borrower to repay the debt as per schedule of the repayment. Before allowing credit facility a banker should be satisfied that the applicant qualifies the following five essentials which may be termed as $5 \mathrm{Cs}$, namely- Character: borrower's integrity, honesty and intention to repay the loan money, Capacity: borrower's business ability, particularly profit making report, Capital: financial strength to cover a business risk, Conditions: it is general business condition, Collateral: borrower's ability to produce additional securities [5]. All types of credit facilities of commercial banks can be broadly classified into two groups: funded and non funded credit. Any type of credit facility which involve direct outflow of Bank's fund on account of borrower is termed as funded credit facility. Funded credit facilities may be classified into four major types: loans, cash credit (CC), overdraft (OD) and bill discounted and purchased. Any type of credit facility where there is no involvement of direct outflow of Bank's fund on account of borrower is termed as non funded credit facility. Non funded credit facilities may turn into funded facilities at times. As such, liabilities against these types of credit facilities are termed as 'contingent liability'. The major non funded credit facilities are: letters of credit (L/C), bid bond, performance bond, advance/payment guarantee and foreign counter guarantee etc. [6].

The crucial purpose of this study is to make possible suggestions to improve present credit situation prevailing in the banking sector in Bangladesh by analyzing a reputed commercial bank's credit activity. It will also assist the ongoing improvement of the banking sector by identifying the lacking in the existing credit risk assessment and management system and minimize so by adopting a standardized approach.

\section{Literature Review}

Although the major objective of credit rating is to determine the ability and willingness of a borrower to pay at the agreed terms, the rating does a bit more than just classifying the borrowers into 'pass' and 'fail' categories. Treacy and Carey (2000) [7] suggested that in designing a credit rating system, a bank should consider numerous factors, including cost, efficiency of information gathering, consistency of rating produced, staff incentives, nature of a bank's business, and uses to be made of the internal ratings. When assigning a loan applicant to a particular grade, Crouhy et al. (2001) [8] suggested that banks should analyze three different categories of variables - quantitative, qualitative and legal. The quantitative analysis concentrates mainly on financial analysis and is often based on a firm's financial reports. The four main quantitative factors used in the assessment model include net income, total operating income, total equity capital and total asset values.

Despite the advances in science and technology that allow the development of expert system or statistical classification models, human judgment is still an important ingredient in the credit assessment process. According to Treacy and Carey (2000) [7], the rating process almost always involves the exercise of human judgment because factors to be considered in assigning a rating and the weights given to each factor can differ significantly among borrowers. Indeed, experienced lenders take credit ratings and reports as inputs for decision-making process. The key reason for the models to be tempered with judgment and common sense is because they do not fully explain the subjective factors involved in the rating.

Credit assessment helps the banker to ensure selection of right type of loan proposals/projects/ventures/enterprise and right type of borrower. For selecting the borrower security should not the only thing to be relied upon. So responsibilities of the bankers to investigate the client from different view point i.e. the strength and weak ness of the client so that the client will be able to repay the bank loan as repayment schedule with profit. To prevent future financial crises, it is absolutely necessary to improve the borrowers' financial literacy, the lenders' process of transparency and to better assess loan product affordability and suitability.

Ernst \& Young [9], on behalf of the Institute of International Finance (IIF), surveyed 62 of the largest banks to assess banks' progress in the implementation of risk governance principles and practices outlined in the 2008 IIF report. Across the board, banks have embraced the IIF's principles to advance risk management, risk governance and risk appetite. Among the 62 chief risk officers (CROs) and senior risk executives who participated in our survey, the most common improvements cited included strengthened management, increased control of liquidity risk and refined reporting systems [9].

\section{Credit Assessment Area of Commercial Bank}

The major credit risk is assessed by the bank while assessing a credit proposal through Borrower Analysis. Full particulars of the proprietor, partners, directors etc. are examined and their management capability is ascertained in this analysis. Overall performance and credit status of the allied concerns of the client i.e. group is also assessed. Industry Analysis include before extending credit in an area, over all business conditions of that area or sector is critically examined, prospects and problems are ascertained by the bank officials. Demand and supply of the concerned goods and services, demand and supply gap, contribution of the borrower in meeting the gap, strength and weakness of the borrower \& their competitors to be accurately assessed. Supplier/ Buyer Analysis on whether the borrower depends on a single or a very few customer or gets the supply of the raw materials/ dealing items from a single supplier. Such sales and supply concentration are given a very careful consideration, because it has significant impact on the 
future viability of the borrower. Historical Financial Analysis covers a minimum of 3 years historical financial statements of the borrower to be presented. The analysis addresses the quality and sustainability of earnings, cash flow and the strength of the borrower's balance sheet. Projected Financial Performance Analysis includes where term facilities (tenor more than 1 year) are proposed, indicating an analysis of the sufficiency of cash flow to service debt repayments. Loans should not be granted if projected cash flow is insufficient to repay debts. Account Conduct involves, for existing borrowers, historic performance in meeting repayment obligations (trade payments, cheques, interest and principal payments etc.) should be addressed. Credit- debit summation, maximumminimum balance, recycling and adjustment of the liability are looked into which generally will back renewal decision. Adherence to Lending Guidelines means credit proposals to be prepared in line with bank's lending guidelines. Mitigating Factors consider credit assessment, possible risks, such as margin sustainability or volatility, over stocking or debtor issues, rapid growth, acquisition or expansion, new business line expansion, management changes or succession issues, customer or supplier concentrations and lack of transparency or industry issues. Loan Structure include amount and tenor of loan is fixed justifiably depending on income generation prospect, projected repayment capacity and the purpose of the loan. Securities that obtained are acceptable, valuable, and easily marketable \& defect less (in title). Valuation of security is properly assessed. Securities are comprised of primary and collateral and are adequately insured. Name lending policy depending only on the fame and reputation of a borrower should be avoided. All associated risks, lending fundamentals and a thorough financial analysis must be made.

\section{Credit Risk Grading Standpoint}

The credit risk grading (CRG) system is vital for a commercial bank to take decisions both at the pre-sanction stage as well as post-sanction stage. Figure 1 illustrates that at the pre-sanction stage, credit grading helps the sanctioning authority to decide whether to sanction loan or not, price and extent of the loan etc. whereas at the postsanction stage, the bank can decide about depth of the review or renewal, frequency of review etc. [10].

There may be eight categories of grades of credit proposed CRG scale. In Superior Grade credit facilities are fully secured by cash deposits, government guarantee etc. whereas in Good Grade the repayment capacity of the borrower is strong; the borrower has excellent liquidity and low leverage. In Acceptable Grade the borrowers have adequate liquidity, cash flow and earnings. They can demonstrate consistent earnings, cash flow and have a good track record but not as good grade borrower. Credit is secured by acceptable collateral. Marginal/ Watch List Grade deserves greater attention due to conditions affecting the borrower, the industry or the economic environment. Early warning signals of emerging business credit detected. Loan repayments routinely fall past due. Account conduct is poor. In Special Mention Grade deserves close attention of the management otherwise a deterioration of the repayment prospects of the borrower may result. Financial condition of Substandard Grade is weak and jeopardizes the full settlement of loans. Bangladesh Bank criteria for substandard credit shall apply. In Doubtful Grade full repayment of principal and interest is unlikely and the possibility of loss is extremely high. In Bad \& Loss Grade credit has long outstanding with no progress in obtaining repayment or on the verge of wind up/liquidation. Bangladesh Bank guidelines for timely write off of bad loans must be adhered to legal procedures/suit initiated [10].

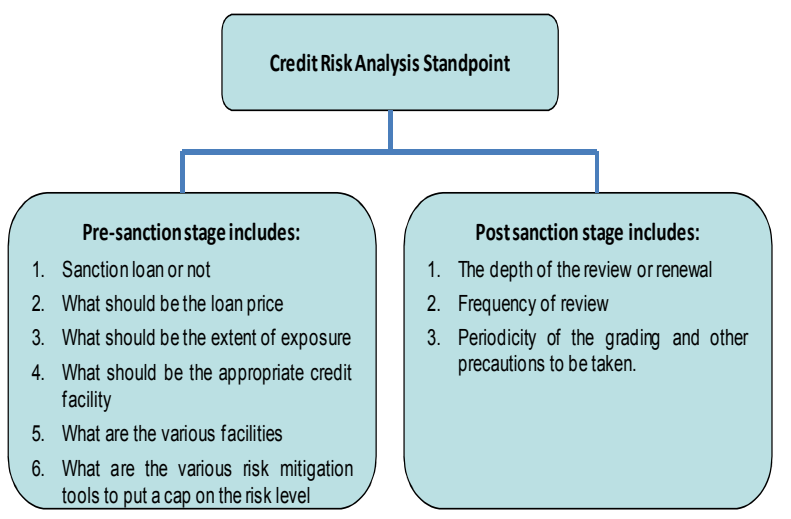

Figure 1. Factors to be considered by the credit sanctioning authority of the bank at pre-sanction or post-sanction stages

\section{Case Study of a Commercial Bank in Credit Assessment}

A well established scheduled commercial bank ' $\mathrm{X}$ ' was incorporated as a public limited company under the Companies Act 1994 and obtained license from Bangladesh Bank in 1995. Authorized and paid up capital of the bank is 4000 and 2000 million Tk. respectively. Number of branches of the bank is now 102 throughout the country and number of shareholders are 8409 . It maintains business link with different Government and Non Government Organizations.

The bank believes in its uncompromising commitment to fulfill its customer's needs and satisfaction and to become their first choice in banking. The long-term goal is to maximize the wealth of the shareholders and short term goal is to earn satisfactory rate of return on investment providing wide range of banking services.

\section{Loan Sanction and Approval Procedure}

The bank gives emphasis on a comprehensive view of the capital, capacity, integrity of the borrower, adequacy, nature of security, compliance with all legal formalities, 
and completion of all documentation and finally a constant watch on the account. Where advances are granted against the guarantee of a third party, the guarantor must be subjected to the same credit assessment as made for the principal borrower. Some important element of a good loan policy include: the required adequate documentation that is necessary for each loan application must be kept in the Bank's credit files (required financial statements, security agreements etc.), a presentation of policies and procedures for setting loan interest rates and fees and the terms for repayment of loans are also required, lines of responsibility in making assignments and reporting information within the loan department, operating procedures for soliciting, reviewing, evaluating, and making decisions on customer loan applications etc. [11]. The stages of credit approval are done both at the branches and at the corporate office level according to the sequence of Figure 2.

\begin{tabular}{|c|}
\hline $\begin{array}{l}\text { At first the client applies for the loan in a prescribed form to the branch. It covers the type of } \\
\text { loan facility, personal information, and business information. Branch Manager or the Officer-in- } \\
\text { charge of the credit department conducts the initial interview with the customer. }\end{array}$ \\
\hline $\begin{array}{l}\text { The bank sends a letter to Credit Information Bureau (CIB) of Bangladesh Bank for obtaining a } \\
\text { creditinquiry report of the customer from them. }\end{array}$ \\
\hline $\begin{array}{l}\text { If CIB report is positive on that particular borrower and categorized as a prospective borrower } \\
\text { then the bank will scrutinize the required documents: financial documents of the company for } \\
\text { the last three to five years \& personal net worth of the borrower(s). }\end{array}$ \\
\hline Bank officials of the credit department will inspect the project for which the loan is applied. \\
\hline $\begin{array}{l}\text { This is the credit analysis phase. Loan proposal is evaluated by financial spreadsheet analysis } \\
\text { which consists of a series of quantitative techniques. Here analyze the risks associated with a } \\
\text { particular loan and to judge the financial soundness and worthiness of the borrower. }\end{array}$ \\
\hline $\begin{array}{l}\text { The produced documents related with the collateral will be asked to regularize or up to date by } \\
\text { the applicant. }\end{array}$ \\
\hline $\begin{array}{l}\text { At this stage based on the analyses the branch prepares a loan proposal. The proposal contains, } \\
\text { Name of the borrower (s), Nature of credit, Purpose of the credit, Extent of the credit, Collateral, } \\
\text { Margin, Rate of interest, Repayment schedule and Validity. }\end{array}$ \\
\hline $\begin{array}{l}\text { The credit line is approved by using the manager's discretionary power and considering DBBL's } \\
\text { lending criteria. Then issue a sanction letter to the client. If the value of the credit line is above } \\
\text { the branch manager's limit then it is send to head office or zonal office for final approval with } \\
\text { detailed information regarding the client(s), credit analysis and security papers. }\end{array}$ \\
\hline $\begin{array}{l}\text { Head office processes the credit proposal and afterwards puts forward for approval from the } \\
\text { board of directors. }\end{array}$ \\
\hline $\begin{array}{l}\text { An approval letter is sent to the branch. The branch then issues a sanction letter to the borrower } \\
\text { with a duplicate copy which is duly signed by the borrower and is retumed to the branch of the } \\
\text { bank. }\end{array}$ \\
\hline $\begin{array}{l}\text { After issuing the sanction advice, the bank will collect necessary charge documents. Charge } \\
\text { documents vary on the basis of types of facility, types of collateral. }\end{array}$ \\
\hline $\begin{array}{l}\text { Finally loan is disbursed by the branch through a loan account in the name of the borrower and } \\
\text { monitoring of the loan starts formally. }\end{array}$ \\
\hline
\end{tabular}

Figure 2. Stages of credit approval procedure

\section{Methodology of the Study}

This is an evocative type of research. Theoretical and practical studies have also been incorporated. It concerns with the systems and practices that exist, beliefs and processes that are ongoing, effects that are being felt or trends that are developing in the banking sector. Both the primary and secondary data have been collected for this study. Secondary information is collected through different manuals, periodicals and publications of Bangladesh Bank, annual reports of a well known private commercial bank in Bangladesh, the Ministry of Finance and other related publications. Primary sources are face to face conversation with the executives and officers, practical desk workers and personal observation.

\section{Result and Discussion}

Data have been analyzed in accordance with the research design. Time series analysis, trend analysis and regression analysis have been performed for the analysis of data. Initially the secondary data has been analyzed by editing, coding and collecting. Qualitative analysis is based on the macroeconomic variables and credit policy provided by Bangladesh Bank, the central bank of Bangladesh.

\subsection{Loans \& Advances and Income from Investment}

The loan amount and income from investment of the specified bank from 2006 to 2010 were analyzed. In the year 2006 loan amount was 30456.32 million which was decreased to 29403.12 million in 2007. The highest loan was found in 2010 as 67657.67 million taka which is $39 \%$ more than the year 2009 (Table 1, Figure 3). On the other hand, in 2006 the income from investment was 428.97 which increased to 630.86 in the year 2007. The maximum income from investment (1334.16 million) was in 2009. Again in the year 2010 the income from investment was dropped to 1278.8 million taka. The data has been shown in Table 1 as well as in Figure 3.

Table 1. Loans and advances and income from investment (in Million Taka) of the specified bank in 2006-2010

\begin{tabular}{llllll}
\hline Particulars & $\mathbf{2 0 0 6}$ & $\mathbf{2 0 0 7}$ & $\mathbf{2 0 0 8}$ & $\mathbf{2 0 0 9}$ & $\mathbf{2 0 1 0}$ \\
\hline $\begin{array}{l}\text { Loans \& } \\
\text { Advances } \\
\begin{array}{l}\text { Income } \\
\text { from }\end{array}\end{array}$ & 30456.32 & 29403.12 & 41698.32 & 48410.99 & 67258.88 \\
Investment & 428.97 & 630.86 & 621.73 & 1334.16 & 1278.80 \\
\hline
\end{tabular}

From the time series analysis we get the equation as follows:

$\mathrm{Y}=36105.32+8065.69 \mathrm{t}$

where, $\mathrm{Y}=$ Loans \& Advances (in Million Tk.), $\mathrm{t}=$ Time (Year)

This means the bank on an average, provided loans \& advances of Tk. 36105.32 million per year. The inter year variation in loans \& advances provided by the bank measured in terms of million Tk. 8065.69. There has been rising trend in loans \& advances during the period from 2006 to 2010 by considering the base year 2007 and sustain positive trend of business during the period.

Loan \& advance has been assumed as dependent variable, denoted by $\mathrm{Y}$ whereas deposit as independent variable, denoted by $\mathrm{X}$, the regression equation was estimated as follows:

$\mathrm{Y}=-327.24+0.7698 \mathrm{X}$

It indicates that for one taka increase in deposit, loan will be increased by 0.7698 paisa. The amount $(-327.24)$ is 
fixed which means that if deposit is zero, there will be no loan and the bank will have to carry a liability of Tk. 327.24 .
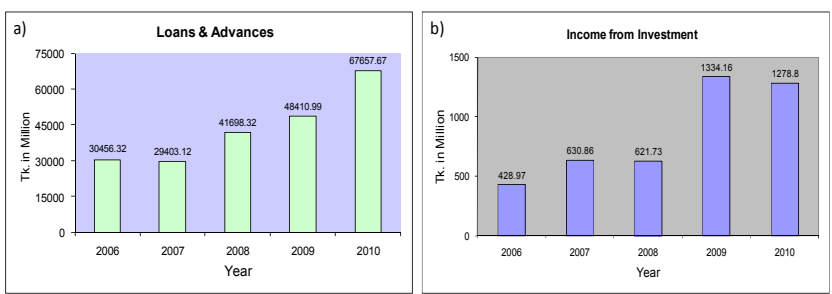

Figure 3. Year-wise a) loans and advances and b) income from investment of the specified bank

\subsection{Sector Wise Loans, Advances and Lease}

In 2010, the maximum amount of loan (23923.44 million Tk.) was allocated to the textile sector which was $35.57 \%$ of the total allocation of that year. On the other hand, service industries, food $\&$ allied industries, energy $\&$ power and bank \& other financial institutions were allocated $8.41 \%, 4.65 \%, 4.36 \%$ and $3.02 \%$ respectively (Figure 4 ).

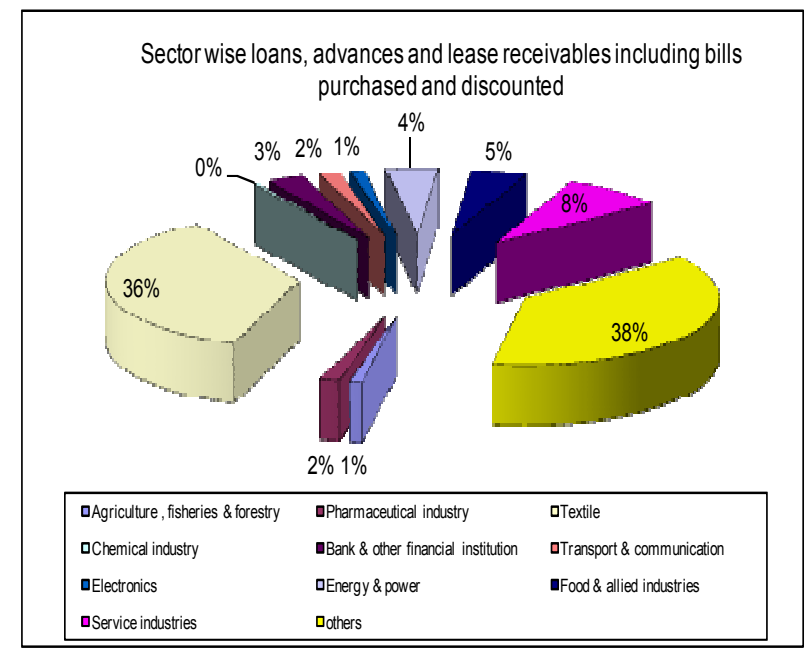

Figure 4. Graphical representation of sector wise loans, advances and lease receivables including bills purchased and discounted during the year 2010

\subsection{Outstanding Loan Status}

Table 2. Outstanding loan (OL) status in 2010

\begin{tabular}{|c|c|c|c|c|c|}
\hline \multirow{2}{*}{$\begin{array}{l}\text { Total OL } \\
\text { (Tk. in } \\
\text { Million) }\end{array}$} & \multirow{2}{*}{$\begin{array}{l}\text { Amount of } \\
\text { Unclassified } \\
\text { Loans }\end{array}$} & \multicolumn{3}{|c|}{ Classified Loan (CL) } & \multirow{2}{*}{$\begin{array}{l}\text { Total } \\
\text { CL }\end{array}$} \\
\hline & & SS & DF & BL & \\
\hline \multirow{2}{*}{67657.67} & 65991.99 & 18.3 & 590.25 & 1057.13 & 1665.67 \\
\hline & $97.54 \%$ & $0.03 \%$ & $0.87 \%$ & $1.56 \%$ & $2.46 \%$ \\
\hline
\end{tabular}

The total classified loan of the bank was $2.46 \%$ as on December 31, 2010 which was the same in the year 2009. Total outstanding loan was 67657.67 million Tk (Table 2). Among the classified loan substandard, doubtful and bad \& loss categorized loan were $0.03 \%, 0.87 \%$ and $1.56 \%$ respectively (Figure 5).

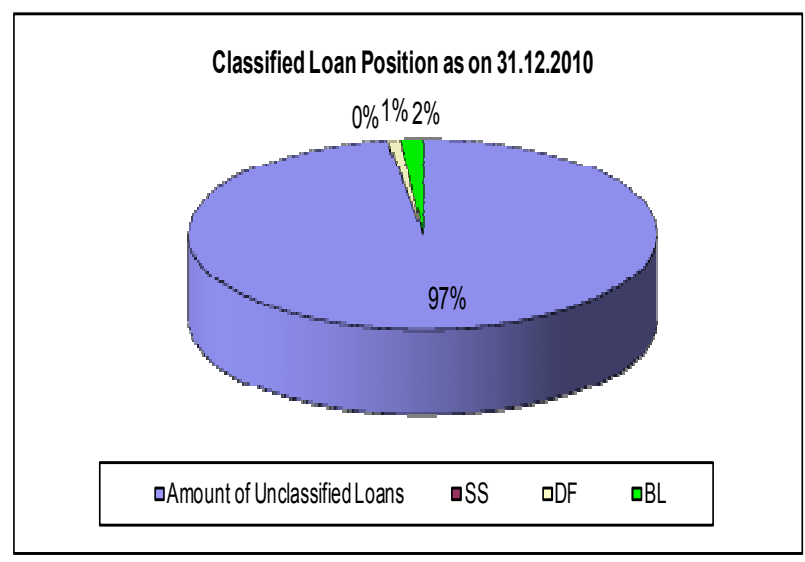

Figure 5. Classified loan positions as on December 31, 2010

\subsection{Growth Rate}

The total loans \& advances of the bank increased from Tk.14976.06 million in 2004 to Tk.67657.67 million in 2010. The growth rate in loans \& advances over the previous year and over the base year (2004) has been analyzed in Table 3. The highest growth in loans \& advances was in the year $2006(51.26 \%)$. In the year 2010 growth rate in loans \& advances was $39.76 \%$ over that of the year 2009. Loans \& advances over the previous years witnessed a positive growth rate except 2007. Compound growth rate of loans \& advances was $29.99 \%$ during the period.

Table 3. Growth rates of loans and advances

\begin{tabular}{lllll}
\hline Year & $\begin{array}{l}\text { Loans \& } \\
\text { Advances }\end{array}$ & $\begin{array}{l}\text { Growth rate } \\
\text { over the } \\
\text { previous year }\end{array}$ & $\begin{array}{l}\text { Growth rate } \\
\text { over the base } \\
\text { year (2004) }\end{array}$ & $\begin{array}{l}\text { Average } \\
\text { Growth } \\
\text { Rate }\end{array}$ \\
\hline 2004 & 14976.06 & - & - & \\
2005 & 20134.74 & $34.45 \%$ & $34.45 \%$ & \\
2006 & 30456.32 & $51.26 \%$ & $103.37 \%$ & \\
2007 & 29403.12 & $-3.46 \%$ & $96.33 \%$ & $29.99 \%$ \\
2008 & 41698.32 & $41.82 \%$ & $178.43 \%$ & \\
2009 & 48410.99 & $16.10 \%$ & $223.26 \%$ & \\
2010 & 67657.67 & $39.76 \%$ & $351.77 \%$ & \\
\hline
\end{tabular}

\section{Major Findings and Recommendations}

The major findings as revealed from the study are as under:

- $\quad$ To improve credit management system of bank credit management policy provides directional guidelines to all concerned parties in credit operations.

- $\quad$ Lending procedure of a bank possesses some implied risk. Proper risk management and policy regulation can help to reduce such risk to a great extent. The bank maintains centralized credit approval system to mitigate the credit risk at sanction stage.

- $\quad$ During the period the average growth rate of loans \& advances was (29.99\%) which may be entitled as sustainable growth of the bank. 
- Total classified of loans \& advances is $2.46 \%$ in 2010 which was the same in the year 2009. It indicates the implementation of better risk management in loans and advances. The bank always follow the regulatory requirement regarding provisioning against classified loan and advances.

From the above findings it can be concluded that the bank, maintained standard credit management policy in the changing market situation to establish a set of credit management policy. By analyzing the data it has been observed that the bank is in better position in respect of credit assessment procedure exercising in the bank. However, the following recommendations may be considered:

- The management of the bank should review their systems, policies, processes and product prices in line with the changing market reality.

- In order to reduce the classified loans and advances bank should be more cautious regarding preparing credit proposal, approval, disbursement, monitoring and documentation formalities for a loan.

- Diversification of loan portfolio in different sectors is required to reduce large loan risk.

- Bank should focus more on agricultural and industrial credit and discourage consumer durable finance.

- SME is the thrust sector of Bangladesh economy and Government also put stress to financial sectors to provide more finance to SME sector for microeconomic development. The Bank should formulate separate SME financing guidelines and enhance credit facility to this sector.

- Bank should make proper and exhaustive documentation before disbursement and to ensure proper supervision, monitoring and follow up of each credit.

\section{Conclusion}

Like any other segment of the economic policy, credit is very important for any financial institution as it generates profit and gear up economic activities of the country. In other words, credit is a business entity and it is input in the production process of the country. Since credit has an inherent risk, therefore proper utilization of the loans are essential to meet the requirements of the borrower. The loan applied for by the borrower must not be employed for unproductive purpose. In this regard, the bank must closely follow the progress of the loan and the way the borrower is utilizing the funds. In the assessment processes the bank will determine any fraudulent activities on the part of the borrower. The bank always trying to improve their credit policy for minimizing loss and maximizing profit and various measures are undertaken to develop the credit management system.

\section{References}

[1] Galbis, V. (1977). "Financial intermediation and economic growth in less developed countries: A theoretical approach". The Journal of Development Studies, 13 (2), pp 58-72.

[2] Chaplin, G., Emblow, A. and Michael, I. (2000). "Banking system liquidity: developments and issues". Financial Stability Report (Bank of England), December issue, pp 93112.

[3] Allen, F. and Santomero, A. M. (1997). "The theory of financial intermediation". Journal of Banking and Finance, 21, pp 1461-1485.

[4] Basel Committee on Banking Supervision. Principles for the management of credit risk - Consultative Paper - November, 1999.

[5] Golin, J. (2005). "The Bank Credit Analysis Handbook". John Wiley \& Sons (Asia) Pre Ltd.

[6] Standard Chartered Bank. (2001). "Commercial loan to business- industry risk analysis". Journal 22, December.

[7] Treacy, W. F. and Carey, S. M. (2000). "Credit risk rating system at large US banks". Journal of Banking and Finance, 24, pp 167-201.

[8] Crouhy, M., Galai, D. and Mark, R. (2001). "Prototype risk rating system". Journal of Banking and Finance, 25(1), pp 47-95.

[9] Ernst and Young. (2011). "Making strides in financial services management".

[10] Kabir, G., Jahan, I., Chisty, M. H. and Hasin, M. A. A. (2010). "Credit risk assessment and evaluation system for industrial project". International Journal of Trade Economics and Finance, 1(4), pp 331-341.

[11] Rose, P. S. and Hudgin, S. C. (2008). "Providing loans to businesses and consumers. In: Bank Management and Financial Services". The Mcgrow-Hill Companies, pp 513541. 